\title{
The Evolution Of Strategies: Multinational Subsidiaries Operating In China
}

Ronald J. Salazar, University of Houston-Victoria, USA Jifu Wang, University of Houston-Victoria, USA

\begin{abstract}
This is a study of the evolution of strategies of large multinational (MNC) firms doing business in China. Using the TOWS approach (Weirich, 1982) we classified the strategic posture of MNC subsidiaries in China into four discrete frames based on a survey of large firms. The results of our study applying the TOWS approach have allowed us to expose the trend of strategic evolution. We find that the primary investment motivation of MNS in China has changed from "low labor cost" to "exploiting Chinese market". We report the motivations, actions, and aspirations of the managers of largest multinational subsidiaries operating there.
\end{abstract}

Keywords: Multinational Subsidiaries Operating in China; Multinational Corporations

\section{INTRODUCTION}<smiles>c1ccccc1</smiles>
hat are the dominant strategies employed by multinational corporations in establishing MNC subsidiaries in China? What are the keys to success? How have successful strategies evolved over time? This paper presents the results of our in-depth survey and analysis of the entry and evolution of MNC subsidiaries' strategies over a fifteen year period and reports the alternative pathways to success identified by a large sample of firms. Over the last 20 years, interrelations between countries worldwide have escalated due in large part to rapid acceleration in the rate of foreign direct investments (FDI). Traditionally, researchers contended that competitive advantage was developed at the level of the corporate headquarters and "leveraged overseas through the transfer of technology to a network of foreign subsidiaries" (Birkinshaw \& Hood, 1998: 773). Other scholars, like Bartlett and Ghoshal (1989), developed models focused on the role multinational subsidiaries have played to the development and evolution of competitive advantage. Today scholars realize that subsidiaries are established for a variety of reasons - to exploit or to develop new markets, to develop greater efficiencies, or to access closer or less costly resources. In the early 1990s, the former Soviet block countries, particularly the Czech Republic, Hungary and Poland, were the targets of much FDI largely because of the market opportunities (Steensma, Tihanyi, Lyles \& Dhanaraj, 2005). Today, however, the attention of the world has turned to China—a country rich in FDI and international trade.

As of 2002, more than 400 of the 500 largest worldwide MNCs had already invested in China and most had at least one subsidiary in the country. As we will see, this population represents a great deal of diversity and complexity. Therefore, China provides an excellent context for understanding the strategies of MNCs and the development of their subsidiaries, especially in light of the direct effect on global venture capital.

This research reports the results of a study of the global strategies and strategic evolution of MNC subsidiaries operating in China. We examine their strategic roles in an attempt to identify the subsidiaries' significance in the internal network system. Our work is theoretically grounded primarily in two theories, the resource based view of the firm (Wernerfelt, 1984) and the organizational learning perspective (Huber, 1991). In order to present our results we have adopted the TOWS matrix classification scheme invented by Weihrich (1982) and have recaptured some of the robustness he envisioned for the technique. Our results suggest that, in general, the subsidiary companies we studied assume a passive arrangement with the host country during the early years of development. However, this posture rapidly evolves to a more active arrangement as the subsidiary grows and develops. 


\section{THEORETICAL BACKGROUND AND LITERATURE REVIEW}

The strategic motives that inspire MNCs to engage in FDI have been a source of discussion for many years among researchers. It has been argued that FDI can "give individual firms a competitive advantage, improve their financial position, increase capacity utilization, and raise technological standards" (Zitta \& Powers, 2003: 275). As is common in previous research, we rely on the resource-based view of the firm (RBV) and the organizational learning perspective (OLP) (Huber, 1991, Steensma, Tihanyi, Lyles \& Dhanaraj, 2005; Das \& Teng, 2000) to understand the initial motives, as well as the growth and development strategies of MNC in China. RBV argues that sustainable competitive advantage is the output of the rarity, inimitability, and non-tradability of intangible resources (Barney, 1991; Grant, 1991). According to Zitta and Powers (2003) firms' primary motivation for investing in foreign markets are either factor-seeking or market-seeking reasons. Typically, firms following factorseeking motivations are looking for resources that can aid in their operations in a foreign country. Such resources can include land, as well as labor resources, or the availability of capital goods (Dunning, 1993, 1998). Companies that are investing for market-seeking purposes are looking for new markets for their products rather than resources to aid in production (Zitta \& Powers, 2003). The resource based view argues that whatever the motive for the investment, successful firm performance is dependent on management's ability to deploy the necessary resources (physical, labor or market) (Barney, 1991).

Complementary to resource based view, the organizational learning perspective focuses on the importance of knowledge acquisition (i.e. drawing on available knowledge, learning from experience, learning by observing other organizations, grafting on to itself components that possess knowledge needed but not possessed by the organization, and noticing or searching for information about the organization's environment and performance) (Huber, 1991) leading to the creation of knowledge-based and firm-based capabilities (Amit \& Schoemaker, 1993). In today's global and highly competitive environment, long term viability and sustainability of a firm requires a combination of both specialized resources and knowledge-based resources. According to Steensma, Tihanyi, Lyles and Dhanaraj (2005: 214), "it is the knowledge-based capabilities that provide the flexibility to realign resources as markets change." Thus, OLP supports Dunning's (1993) theory on market seekers. For example, a market presence might be required in order to adapt a firm's product to specific market requirements. Thus, in the case of operating subsidiaries, the process is more complex than previously believed. The parent company can provide the decision influences (or knowledge resources) that affect the initial deployment of physical resources (in accordance with the resource based perspective). Together with these resources, learning shapes the firms outcomes and competitive posture (Das \& Teng, 1998).

Examining the nature of the initial investment decision from a different perspective, Zitta and Powers (2003: 276) suggest that "possible motivations behind factor- seeking and market-seeking behavior can be categorized in two dimensions - external market factors and internal company reasons." External market motivations include those elements in the foreign market that make that market attractive to a MNC. One such factor revolves around common human resource practices in the host country. The sub-constructs of this factor include such things as labor costs, the degree of unionization, safety and labor policies, and the skill level of workforce (Miller, 1993). Interestingly, strict labor policies in the home country can likewise serve as a motivator to seek FDI opportunities (Hartman, 1984). On the other hand, availability of labor, skill level of labor and the cost of labor may serve as a strong motivator for foreign investment (Zhang, 2001).

One of the most significant factors to market-seeking FDI is size and growth of the host market. Specifically, the developmental stage of the country, projected growth rates and existence of competition in the subject industry are of interest to an MNC. Those companies with extensive international experience often find the less attractive, more uncertain markets of interest to them (Dunning, 1973). Henley, Kirkpatrick and Wilde (1999) and Zhang (2001) pointed to market size as a primary factor for entry into China, which has had unprecedented success in attracting FDI. Likewise, Cheng and Kwan (2000) noted that the vastness of the Chinese market, as well as the rapidly improving infrastructure, made investment attractive.

The political climate in a host country can often make or break FDI decisions. In particular, capital controls, as well as restrictions on the transfer of international funds are among the policies that could cause firms to think twice before investing in a particular country. And, as noted by Zitta and Powers (2003: 277), "when these 
polices lead to prolonged deviation from purchasing power parity so that the real exchange rates change, FDI flows may be altered." Other issues of concern with regard to FDI decisions are antitrust policies, government transfer pricing policies, and intellectual property laws (Brewer, 1993). In addition, other host country laws or customer requirements could force an MNC to undertake activities in that country that the firm would prefer to do elsewhere (Birkinshaw \& Hood, 1998). Much of the extant literature bundles many of these issues together under the term "institutions," which is a measure of a country's political, legal and economic perspectives and practices, which makes comparability across countries problematic (Wei, 2000).

Finally, the impact of interest rates, exchange rate fluctuations and the availability of financing sources in the international capital markets can influence FDI decisions. For example, countries whose currency has recently been devalued provide a generally positive incentive for FDI in the short term (Froot \& Stein, 1989; Zitta \& Powers, 2003). Based on their observation of US FDI, Froot and Stein (1991) found empirical support that FDI increased with currency depreciation. These findings have been consistently supported with regard to short-run movements in exchange rates (Grubert \& Mitti, 1991; Swenson, 1994; Kogurt \& Chang, 1996). By illustration, empirical evidence has shown that China's exchange rate policy played a critical role in its FDI boom from 1981 to 2002, as did the devaluation of the yuan (Xing, 2005).

As previously noted, the motivation for establishing a MNC may be internal to the company. For example, when the home country's market is saturated, many firms might look to the international market as a place for growth and as a means of risk reduction. Likewise, when products require considerable adaptation when marketed in another country, firms often find it favorable to be close to the foreign market and are more apt to invest in foreign operations (Root, 1990).

Today, in particular, there appears to be a stronger desire for firms to have a global orientation, and such growth by international expansion is an "important strategic option for both small and large firms (Lu \& Beamish, 2001: 565). Stavrevski (2007) noted that such outward investments help to improve access to markets which, in turn, provides the benefits of competitive advantage. Succinctly put by Tang and Yu (1990: 476) "world markets provide opportunities for firms to exploit their comparative advantages through international horizontal integration strategies."

Profit has been long considered a motivation for FDI. An early study by Cohen and Rugman (1976) found that by increasing the number of countries a firm operated in and/or increasing the ratio of foreign activities to total activities, US corporations increased profitability. The authors also found that the stability of input costs due to international expansion increased the overall value of the firm through increased market valuation. Tang and $\mathrm{Yu}$ (1990) examined the profit impact to host firms of different production-related strategies employed when entering a foreign market. Their results suggested that FDI generates the highest profit and is the dominate entry strategy for companies as long as they can charge an optimal licensing fee. In a 2007 speech at the11th China International Fair for Investment and Trade (CIFIT) Zoran Stavrevski, Deputy Prime Minister of Macedonia (CIFIT, 2007), stated that while other factors come into play in the FDI decision, profit was clearly the primary motivating factor.

The need for technology and innovation are huge motivating factors for FDI. Countries with a high innovation capacity (the ability to produce and commercialize a flow of innovative technology on a long term basis), serve as a drawing cards for FDI (Furman, Porter \& Stern, 2002). Research spanning three decades has found strong evidence of FDI in countries with highly advanced processes and/or products (Caves, 1971; Orr, 1973; Buckley \& Casson, 1976; Arpan \& Ricks, 1986). In essence, this need for technology and innovation can be viewed as a "knowledge-seeking" motivation for FDI.

While many motives exist for a firm to establish subsidiaries, the growth and development of that subsidiary is greatly impacted by the level of development in the host country (Steensma, Tihanyi, Lyles \& Dhanaraj, 2005). Svetlicic and Rojec (1994) suggested that transitioning economies often were characterized by a resource gap since some of the basic building blocks (markets, managerial skills, infrastructure, regulatory environment, etc.) were not yet fully developed. However, this is not the case in the rapidly industrializing regions of China. Consequently, the steady development of China's economy and the increasing purchasing power of its consumers make it extremely attractive to MNCs (Makinoa, S., et al., 2004) as well as a fertile research base for this study. 
Although from its introduction, the TOWS matrix has been intended as a dynamic classification tool in complex business situations (Weihrich, 1982, pg. 71) its application in the management literature until recently has been limited. Its author consulted to a manufacturer of products from aircraft, to automobiles to recreational vehicles and advocated its application to firms in multiple industries, across national borders and for multiple time periods, most notably including the future. The technique has again been taken up and has recently been used as a part of fuzzy SWOT Analysis (Ghazinoory \& Memariani, 2007), to find outlets for teaching home economics (Horne, \& Kerr, 2003), for improving innovation strategies for credit departments (Chun-Chu, L, 2007), for developing strategies for a single Croatian insurance company (Božac \& Tipurić, 2008) and for improving the national competitiveness of southeastern European countries (Kersan-Škabić \& Tijanić, 2009). We employ the concepts imbedded in the technique here for the purpose of classifying the multinational subsidiaries we have studied.

\section{METHODOLOGY}

The targeted companies for this study are multinational subsidiaries (MNS) with operations in China. Since we wanted to examine subsidiaries with a significant presence in the country we narrowed our target population to subsidiaries where the parent corporation maintained $50 \%$ or more ownership or those where the parent company had a dominant plurality of shares if ownership was less than 50\%. A total of 400 survey questionnaires were mailed to top management officials of subsidiaries in more than 30 Chinese cities, including Beijing, Shanghai, Tianjing, Guangzhou, Fuzhou, Suzhou, Shenzhen, Zhuhai, Shenyang, Zhangchun, to name a few. If the subsidiary was the result of a joint venture, we surveyed executives from the foreign holding firm as well as the Chinese partner to cross-validate the information we gathered. Follow up telephone calls and e-mails were employed to encourage participation and to clarify and enrich responses where necessary.

A total of one hundred-fifty questionnaires were returned for a response rate of thirty-seven point five percent. Of those returned, twenty-two questionnaires were incomplete and therefore unusable, resulting in a sample of 128 firms for the first phase of our study. Of these MNS, twenty-eight (21.9\%) were US subsidiaries, twenty-two (17.2\%) were Japanese, twenty-five (19.5\%) were from countries in the European Union, forty-three (33.6\%) were South Korean; and the remaining eight (7.8\%) firms were from other countries (see Figure 1 below). A total of one hundred forty-five questionnaires were useable for second phase of our work. The second phase of our study began by classifying the responses of each firm as to the dominant strategic approach reflected by the responses to our questions. The respondents were asked to rank their own strategic priorities from among a set of priorities we suggested for three discrete periods of time. The first period (what we will call "on entry") was at the time of the firm entered the market. This was true whether the firm was new to the country, the creation of a new entity or whether it was the result of a new joint venture or the result of new investment in an existing entity. The second time period reflected in our findings is the present time. Again, respondents were asked to rank their own strategic priorities from among a set of priorities we suggested to them. Finally, respondents were asked to rank their own strategic priorities for the future from among a set of priorities we suggested to them. The term "the future" was defined as having a time horizon of three to five years. The responses were arrayed within each time period according to rank. Then, the proportion of respondents assigning the same rank to the strategic priority was calculated. The results are presented below (Tables $3-6$ ) along with our descriptions of the trends we observed and clarifications made possible by follow-up communications with respondents. 
Table 1 Respondent Statistics

\begin{tabular}{|c|c|c|c|}
\hline Characteristics & Firm Classification & $n$ & Percentage $(\%)$ \\
\hline Country Origin & $\begin{array}{c}\text { South Korea } \\
\text { USA } \\
\text { European Union } \\
\text { Japan } \\
\text { Others } \\
\text { Singapore } \\
\text { Thailand } \\
\text { Australia } \\
\text { Canada } \\
\text { Malaysia } \\
\text { Swiss }\end{array}$ & $\begin{array}{l}43 \\
28 \\
25 \\
22 \\
10 \\
4 \\
2 \\
1 \\
1 \\
1 \\
1\end{array}$ & $\begin{array}{c}33.6 \\
21.9 \\
19.5 \\
17.2 \\
7.8 \\
3.1 \\
1.6 \\
0.8 \\
0.8 \\
0.8 \\
0.8\end{array}$ \\
\hline Firm Nature & $\begin{array}{c}\text { Foreign Owned } \\
\text { Foreign Holding } \\
\text { Joint Venture }\end{array}$ & $\begin{array}{c}91 \\
34 \\
3 \\
\end{array}$ & $\begin{array}{c}71.1 \\
26.6 \\
2.3 \\
\end{array}$ \\
\hline Headquarters Location & $\begin{array}{c}\text { China Headquarters } \\
\text { Global Headquarters } \\
\text { Asia Pacific Headquarters } \\
\text { Big China Headquarters } \\
\text { Missing Data } \\
\text { Others }\end{array}$ & $\begin{array}{c}33 \\
31 \\
27 \\
7 \\
17 \\
13\end{array}$ & $\begin{array}{c}25.8 \\
24.2 \\
21.1 \\
5.5 \\
13.3 \\
10.2\end{array}$ \\
\hline Industry & $\begin{array}{c}\text { Electronics } \\
\text { Textile } \\
\text { Chemistry and Pharmaceutical } \\
\text { Iron, Steel, Mechanics and Engineering } \\
\text { Auto Manufacturing } \\
\text { Food and Beverages } \\
\text { Commerce and Trade } \\
\text { Transportation } \\
\text { Tele-Communications } \\
\text { Finance and Insurance } \\
\text { Consulting } \\
\text { Others } \\
\text { Gasoline and Mining } \\
\text { Real Estate } \\
\text { Mass Communication }\end{array}$ & $\begin{array}{l}35 \\
23 \\
15 \\
13 \\
9 \\
9 \\
7 \\
5 \\
3 \\
2 \\
2 \\
2 \\
1 \\
1 \\
1\end{array}$ & $\begin{array}{c}27.3 \\
18.0 \\
11.7 \\
10.2 \\
7.0 \\
7.0 \\
5.5 \\
3.9 \\
2.3 \\
1.6 \\
1.6 \\
1.6 \\
0.8 \\
0.8 \\
0.8\end{array}$ \\
\hline Respondent Role & $\begin{array}{c}\text { Board Chairman } \\
\text { Board Vice Chairman } \\
\text { Board Members } \\
\text { CEO } \\
\text { Vice CEO } \\
\text { Department Manager } \\
\text { Others } \\
\text { Missing Data }\end{array}$ & \begin{tabular}{c|}
3 \\
4 \\
6 \\
13 \\
16 \\
46 \\
31 \\
9
\end{tabular} & $\begin{array}{c}2.3 \\
3.1 \\
4.7 \\
10.2 \\
12.5 \\
35.9 \\
24.2 \\
7.0\end{array}$ \\
\hline Firm Age & $\begin{array}{c}\text { Less than } 5 \text { years } \\
5-9 \text { years } \\
10-15 \text { years } \\
\text { More than } 15 \text { years } \\
\text { Missing data }\end{array}$ & $\begin{array}{c}43 \\
49 \\
22 \\
10 \\
4\end{array}$ & $\begin{array}{c}33.6 \\
38.3 \\
17.2 \\
7.8 \\
3.1\end{array}$ \\
\hline
\end{tabular}




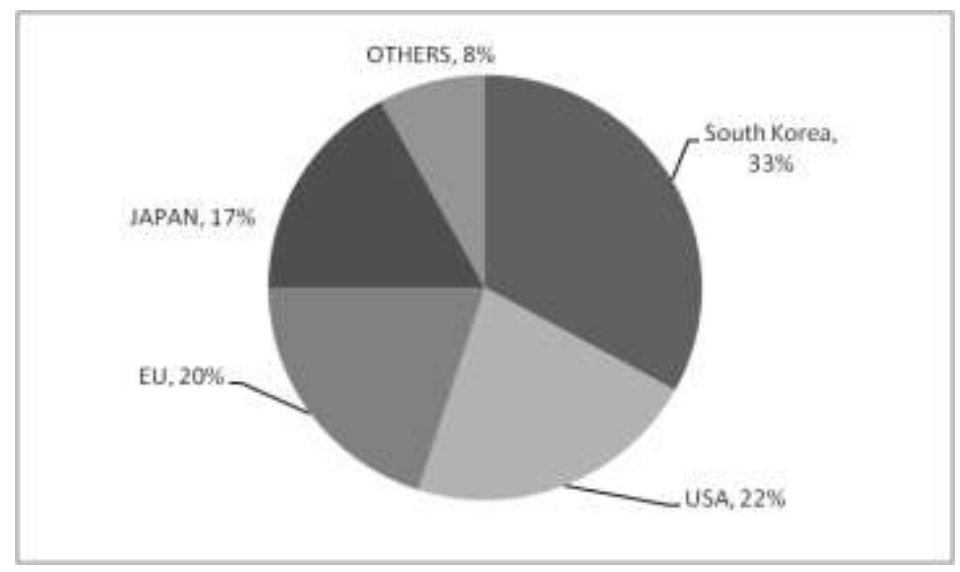

Figure 1 Sample Ownership

\section{DISCUSSION}

Cheap natural resources and an available, low cost labor force was the reason ninety-five percent of respondents selected market exploration and production as the primary role of the subsidiary. In fact, nearly all the production-base subsidiaries ninety-seven point eight percent mentioned cheap labor as a motivating factor suggesting that much of China's FDI followed external market/factor-seeking motivation.

One internal market motivator which as been suggested to be the primary reason for FDI, profit maximization, was not acknowledged as a reason for initial entry into the Chinese market place. The ability of an MNC to maximize profit has long been considered an important reason international expansion (Cohen \& Rugman, 1976). The profit oriented subsidiaries gain profit by exploring price differences and transferring management skills. Hence, these subsidiaries operating in the host country do not intend to gain market share in the host country but anticipate averting the risks incurred in internationalization. For this strategy to be successful the host country must be able to provide local advantages for capital management, including tax advantages as compared to the home country and less strict fund exchange control. However, Chinese foreign exchange policies are not generally considered to be an advantage to subsidiaries (Southwest Economy, 2005). According to our survey MNS frequently establish "no profit-center" subsidiaries in China specifically to avoid dealing with exchange policies. A similar situation appears to be occurring with in the case of natural resources. Coal and petroleum, for example, are under strict government control in China (Lee \& Liu, 1996) and other resources may not always meet quality standards. Consequently, our results show that MNS prefer to purchase raw materials from other global sources.

\section{THE ROLE OF EVOLUTION OF MNC SUBSIDIARIES IN CHINA}

Once the initial role of subsidiaries is adopted, our research suggests that the role does not remain fixed over time. Generally speaking, all the following elements can cause the adjustment of initial role of the subsidiaries: the evolution of the global strategy at the level of the parent company; changes in the environment of the host country and, the development of new strategic targets at the level of the overseas subsidiaries themselves. The first two elements cause the reactive adjustment of the role of subsidiaries akin to that suggested by Miles and Snow (1978). Development targets emerging from overseas subsidiaries lead to a more active adjustment resembling the prospector or analyzer firm suggested by Miles and Snow (1978). 
Table 2 Investment Motives Reported

\begin{tabular}{|c|c|c|}
\hline Investment Motives for MNC's Subsidiaries in China & $\begin{array}{c}\text { Frequency } \\
\mathrm{N}=145\end{array}$ & $\begin{array}{c}\text { Percentage of } \\
\text { Sample (\%) }\end{array}$ \\
\hline Market capacity and Potential of China & 96 & 66.07 \\
\hline To Establish production base in China & 80 & 55.36 \\
\hline To exploit china's Market & 71 & 49.11 \\
\hline To pursue profit & 71 & 49.11 \\
\hline Cheaper labor force & 63 & 43.75 \\
\hline Cheaper Natural Resources and Raw Materials & 23 & 16.07 \\
\hline Export to other countries from China & 22 & 15.18 \\
\hline Seeking Chinese Techniques or joint technology & 13 & 8.93 \\
\hline Competing with Rivals & 13 & 8.93 \\
\hline Following Original customers & 12 & 8.04 \\
\hline To reduce transportation costs & 6 & 4.46 \\
\hline To ensure the quality of products and services & 6 & 4.46 \\
\hline To avoid risks & 5 & 3.57 \\
\hline To carry out R \& D & 4 & 2.68 \\
\hline To transfer out-of-date technologies & 4 & 2.68 \\
\hline To avoid tariff or trade barriers & 3 & 1.78 \\
\hline
\end{tabular}

In order to analyze the evolution (Miles and Snow, 2009) of the strategic role of subsidiaries in MNCs over to time, subsidiaries whose roles have changed were analyzed first. Among altogether 145 sample enterprises whose questionnaire responses we report in this second phase of our study, eleven have adjusted their strategic role. Each of the eleven are production-base subsidiaries (see Figure 2 below), which amounts to only seven point five nine percent $(7.59 \%)$ of the sample. These changes have not occurred in the case of subsidiaries of any other type. Each of the eleven firms identified themselves as having changed have evolved as market pioneers. Once the parent company has determined the global strategic role of its subsidiaries, we find the definition is not easily changed by the MNS, moreover, the increasing stability and maturity of laws and policies in China is also one of the factors that make the strategic role of a subsidiary in China remain relatively stable. Dynamism is the regulatory climate is related to roles changes among subsidiaries generally. Despite the fact that the proportion of subsidiaries that change roles is small, the change of the strategic roles of MNS in China is significant. That is, the roles of some of the MNS in China that have changed have evolved from a production-base role to that of a market-pioneer (Kalyanaram, et. al., 1995). The main reason we have identified explaining this trend is the switch of the investment motivation of the MNC subsidiaries in China.

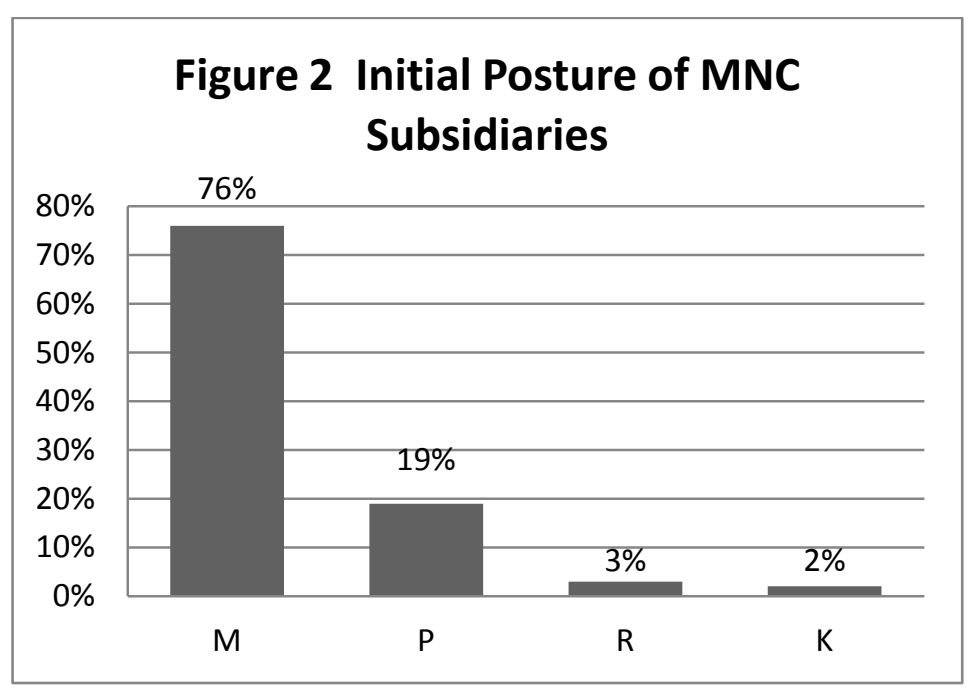

Notes: $\mathrm{M}=$ Market Explorer; $\mathrm{P}=$ Production Based; $\mathrm{R}=$ Risk Avoider; $\mathrm{K}=$ Knowledge Absorber 
Our research shows that the leading two motivations reported by our respondents have changed from "cheap natural resources and an available, low cost labor force" into "exploiting Chinese market" and "establishing a production base in China". Further, the attitude reflected with respect to the domestic raw materials is interesting as well. The former ranking shows that the companies paying attention to the raw materials are 3.95, ranking the fifth in the foreign investment motivations. But now there are only $16.4 \%$ of subsidiaries in China with primary focus on this factor. As we can see, the first investment motivation of MNS subsidiaries in China has changed from "low labor cost" to "exploiting Chinese market". Fully 39.3\% of production-base subsidiaries have changed into market-pioneers among the firms we studied.

The roles adopted by subsidiaries other than "production-based" MNS have not changed. The result of our research indicates "market-explorer" subsidiaries, whose investing motivations have changed, account for eight point two percent $(8.2 \%)$ of the total. Seventy - seven percent $(77 \%)$ of the subsidiaries have existed more than six years. The dominant motivation of these nine subsidiaries has changed from "exploiting Chinese market" to "seeking greater profit".

This indicates that the focus of the role of "market explorer" subsidiaries' investment motivation sometimes changes after a period of long term of growth and development. During initial entry phase, most "market explorer" subsidiaries retain market capacity and potential as the primary goals, focusing on enlarging their share of the Chinese market through long-term growth and development. In this case, the parent company provides strategic resources for its overseas subsidiaries through its global network until the subsidiary enters its strategic expansion phase. It appears that this period of preparation is pivotal in allowing subsidiaries to establish a firm foothold in terms of market knowledge and relationships and then to swiftly leverage them into strategic advantage in this phase. During the expanding phrase, the "market explorer" subsidiaries focus on exploiting Chinese market, as the need for strategic resources from parent company is gradually reduced. Much of the profit created by subsidiaries themselves is used for their own reinvestment purposes. They continue to enlarge their market shares in China for as long as the market permits, establishing and strengthening their leading positions in the industry by production, market and technology innovation.

During the mature phrase, the investment motivation of "market explorer" subsidiaries in China changes again to profit expansion. During this period, the MNS are no longer a drain of the parent's strategic resources. On the contrary, they rapidly create cash and material flows for the parent company, becoming a global or regional strategic business unit of the parent company.

\section{TOWS FRAME ANALYSIS OF STRATEGIES}

MNCS' overseas subsidiaries, like all firms, choose their growth and development strategies based on their perception of the environment and resources they possess. Building on Weirich's (1982) TOWS technique, and following the lead of Oswald, et al, (1997) and Agarwal and Helfat, (2009) we turn our attention to the self reported strategic frame adopted by subsidiaries on entry into China and then compare that frame to that reported at present and forecast for the future. We thereby employ a somewhat expanded version of the TOWS approach to combine the resource-based and learning perspectives. We are able to report the ways this sample of firms has adapted to the circumstances they perceive and bring their unique form of competitive advantage into play. We observe that once MNS managers gain awareness and mastery in dealing with the local and global adversities in the complex host country conditions, they become more broadly able to accomplish the strategic mission of the MNS, namely producing profits. In order to accomplish this, the subsidiary analyzes the company's environments; coming to recognize its advantages and disadvantages, along with the opportunities and threats that exist in observed market conditions, and then carefully selects its growth and developing strategy accordingly depending on its strategic perspective. When the overseas subsidiaries appraise the internal capabilities of the company, the comparative advantage available via its internal network of resources is brought into play, taking into account the parent's advantage contributions to the abilities of oversea subsidiaries. When the subsidiary analyzes its external environment it considers not only the host country's environment, but also changes of the parent country's environment. So the organization-environment analysis of the oversea subsidiaries' strategy is broader than that characteristic of companies operating solely domestically because of the complex growth and development mechanisms we observe in overseas subsidiaries. The results of our survey questionnaire show that: most 
subsidiaries in China report themselves to be in the strength-opportunity frame; the proportion amounts to eightytwo percent of the total. The subsidiaries reporting themselves in the weakness-threat frame account for the next largest proportion. The percentage in the weakness-threat frame is twelve percent which is much higher than those in strength-threat frame (four percent) and weakness-opportunity frame (two percent), as Figure 3 shows below.

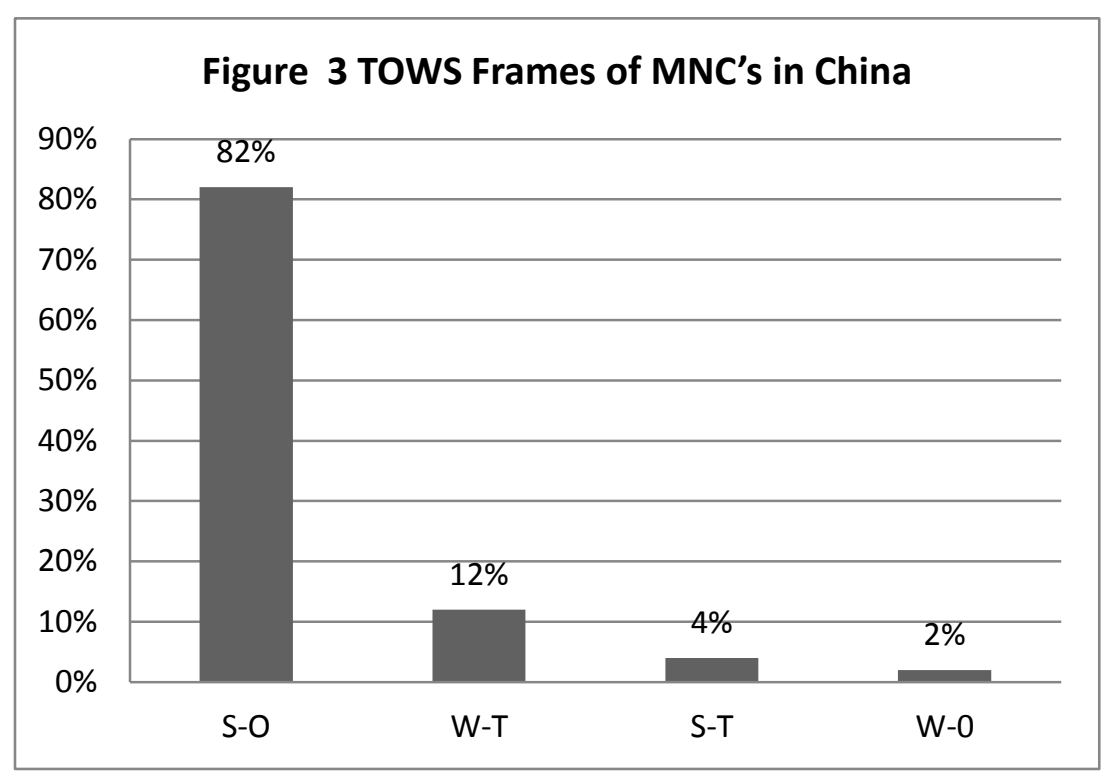

Notes: S-O represents the strength-opportunity quadrant; W-T represents the weakness-threat quadrant; S-T represents the strength-threat quadrant; W-O represents the weakness-opportunity quadrant.

This figure too, will illustrate that the competitive positions of MNS in China have diverged greatly after an initial period of growth and development. Though most subsidiaries in China are in the better positions than they may have originally occupied, a significant minority of firms report themselves in worse conditions characterized by weaknesses and threats.

Nearly ninety percent of firms we sampled considered the competitive environment they faced to be intense. Forty-six of the one hundred forty-five respondent subsidiaries' consider competition to be extremely intense and eighty-four rate competition as very intense. So it can be concluded that at present MNS in China all feel the competing pressure from Chinese market. On one hand, this kind of competing pressure comes from uniqueness of consumer's demands; on the other hand, it comes from the diversification and growing strength of the adversaries. This implies that the nearly half of market entrants hoping to find ripe markets to exploit may have underestimated the inherent challenges. Far from enjoying the benefits usually associated with a ripe growth market alone, the respondents have also had to deal with rapidly strengthening and experienced competitors. Although their initial optimism has been attenuated, respondents report the resulting situation has remained profitable to this point.

After the 1990s, the emergence of foreign companies in large numbers and the abrupt rise of domestic companies both changed former patterns of competition and corresponding companies' business practices. Thus, the cycle time to differentiation of MNS in China is shortened by the presence of multiple, intelligent competitors. Equally interesting is the fact that responding subsidiaries in China in most industries still think the bulk of competitive pressure comes mainly from adversaries with foreign parents in the same or in a related industry, rather than from domestic competitors (seventy-nine percent). This also underscores the fact that although MNS may initially possess advantages vis-a-vis host country competitors, any such advantage is short lived. Many top managers of MNS report that host country competitors are sufficiently weak and under-resourced as to make their inclusion in industry analyses or external benchmarking unnecessary. They choose instead to place the emphasis on analyzing the actions of the foreign-backed MNS that possess both greater resources and competitive abilities. 
As we have observed above, MNS choosing market-developing strategies often enjoy comparative advantages against their host country adversaries. This is particularly true in the fields most impacted by brand image and parent company support. Many market-developing subsidiaries put particular emphasis on the parenting advantages accruing as a result of a favorable brand image of parent company that permitted the MNS to develop robust market share rapidly during the entry phase. During the expansion phase in particular emphasis shifted to overall competitive advantage through product, market and technology innovation to reinforce the market presence further, leading eventually to satisfactory market share and profit.

In contrast, the parent-advantage value of production-base subsidiaries is considerably less related to brand image, with the greatest sources of advantage coming from parent company's financial support and the government relations whose support allows the subsidiary to further develop already established relations with local government and with providers of raw materials. This finding is interesting because it indicates that production-base subsidiaries often rely on more or less continuous support from the parent company to a very large extent and that the form of that reliance tends to remain unchanged over time. Thus, the market-exploration role is unlikely to develop and planned strategic emphasis is more likely to be realized for production based subsidiaries. It is also true that production-base type MNS don't require the influence on the Chinese market potentially available through brand image because most often the products they produce sell either back to the parent or sell to other markets, usually through the global marketing distribution systems already established by the parent. The parent companies of production-based subsidiaries improve their own competitive ability in global markets through reducing their operating costs by the means of tight managerial controls and by making use of the cheaper labor in China.

\section{GENERAL GROWTH AND DEVELOPMENT STRATEGIES}

We have shown that most MNCS' subsidiaries in China adopt direct investment to acquire the resources they need, such as the low-cost labor force, skilled workers and materials supplied in China market. But most successful firms also quickly recognize that competitive advantage built on local resources is all too often easily imitated and cannot last for very long. We observe that successful firms seek out strategic combinations from which the firm can establish a foundation built on overall cost leadership. Regardless of their roles or on their stage of life cycle, the MNS in China always give priority to a strategy of overall cost leadership. Virtually all the firms in our sample attempt to adopt precisely the same strategy! Irrespective of which factors were chosen as leading to the investment initiatives that created the MNS virtually all such firms initially focus on a low-cost labor force and of structural configuration to garner favorable tax treatment and relationships with the government to earn preferential resource costs and funding. This demonstrates that initially, MNS pay more attention to cost control than to any other competitive factor.

This concentration on overall cost leadership quickly expands from seizing the elemental resources required for production to seizing ownership of market share. As firms grow and develop, the subsidiaries gradually recognize the importance of acquiring ownership of competitors. Since anti-trust laws are years in the future many firms choose to limit local competition in this way. Merging with the brand of a local company in China is the best example. The main strategy of MNS overseas investment is acquiring the means of monopoly competition and using brand and scale advantage. MNS in China implement this strategy via two related strategic thrusts. The first is to suppress competition from the local firms whose brands are competitive; the second is to supplant the strongest local brands with their own. For illustrative purposes consider Jiahua, a famous brand of shampoo that was acquired for $\$ 3.14$ million and Kongque, a famous brand of television, formerly an SOE that was acquired for a mere $\$ 3.15$ million. Establishing and retaining friendly relationships with the government remains a priority. MNCS recognize that if they want to locate and successfully negotiate for high value-added activities in China, it is necessary to observe its laws, build close relationships with government officials, to take care of important constituents and to be seen as enthusiastic about public philanthropy.

MNS in China are enthusiastic philanthropists and sponsor many activities and initiatives, which remains the dominant means to establish a good public image. For example, when Proctor and Gamble (USA - P\&G) donated RMB 500,000 to Project Hope they included this information to the public in their brand advertisements. MNS also realize that they can have broad and effective influence on the decision-making process of the government and companies by some special "guanxi"(relationship) with them. For example, Motorola, China's 
largest FDI, has donated RMB 24,000,000 to Project Hope, RMB 14,000,000 to university scholarships and thus has gained the position of assisting the Chinese Ministry of Posts and Telecommunications set industry standards and in training many of its staff for the ministry. By this means, Motorola has managed to make its technical standards the de facto industrial standard of Chinese telecommunications. From its preferential position as a favored partner of the government, Motorola can now enjoy preferential treatment at all levels of government units. This is clear indication of the importance of governmental relations in setting up industrial entry barrier against potential rivals. We found this uniform similarity in the strategic posture of MNS irrespective of their TOWS quadrant frame.

From the results of the questionnaire, we find that MNS in China, in spite of occupying different strategic or frames (S-O, S-T, W-O and W-T), all choose either a developing or a maintaining strategy. Not a single firm in W-T quadrant (presumably the weakest strategic position) chose a retrenchment strategy. Instead, all chose the active maintenance strategy. We believe this can be attributed to an extremely stable regulatory environment. The developing and maintaining strategy posture manifests three distinguishable characteristics common to all of our respondents. First, parenting advantages are important origins of the competitive advantage for all MNS in China. Because of the dependable sustaining resources available from the parent we have already mentioned, such as commitment to the market, brand, capital, R\&D and advantageous transfer pricing etc., MNS subsidiaries in China can afford to choose a developing and maintaining strategy. We note this characteristic with particular interest since many firms reported shock at encountering intense and sustained competition that might have caused firms with lesser support and resources to reconsider and perhaps to withdraw or to retrench. Secondly, we observe intensification of strategic integration and systematization of the investment in the MNS by the parent firms. The management parents of the MNS attach significant strategic importance to the successful future of the large scale investment inherent in establishing a beachhead through an MNS. This is particularly true of subsidiaries within the parent's core business processes or products. Investments in such business domains tend to insist on gaining monopoly power in at least a significant region of the country. Once committed, MNS parents go to extraordinary lengths to sustain and extend the advantage they are able to gain. Once in, there seems to be no looking back. Often this insistence extends to the entire country. Parent firms enter only after their analysis suggests a region or an industry has sufficient potential and upon entering, the MNC enters with sufficient resources for the MNS in terms of scale and commitment to make the investment work. For instance, SONY Japan, investing \$410 million, set up SONY Shanghai with Shanghai Broadcasting Co. Ltd, which is the largest joint venture of electric industry in China. Some MNS exert extraordinary efforts to achieve monopoly in the target industries. One of the most famous of such examples is the large scale M\&A in the rubber industry carried out by the Fukuyama Rubber Co., Ltd. (Japan) in 1997 with the Zhongce Corporation. Today the combined firm, which dominates its several markets, is growing at a thirty percent annual rate. Even in some joint ventures with fewer initial rights to foreign ownership options, the parent company effectively strives to gain the de facto operational and management rights to joint ventures by the means of controlling technologies, marketing channels abroad and brand. The final general strategic characteristic we observed is the tendency toward as much vertical integration as possible. This means that in the growing and developing process, the subsidiaries take more and more activities in their own value chains, attempting to fully integrate R\&D, marketing, production, and service. Local stocks of raw materials and production can reduce the production cost in MNS while localizing $R \& D$ and service served to improve the competence of the MNS in the Chinese market. Localizing HRM functions too can lay the groundwork for providing sufficient human resources for further development of subsidiaries in China. This section has devoted itself to the general growth and development strategies characteristic of MNC subsidiaries in China. Next we report our findings of the differences we observed across TOWS frames.

\section{DIFFERENCES AMONG THE GROWTH AND DEVELOPMENT STRATEGIES BY TOWS FRAME}

Using the TOWS approach (Weirich, 1982) we classified the strategic posture of MNS subsidiaries in China into four discrete frames (or quadrants). Based on our TOWS analysis we were able to expose differences among MNC subsidiaries' self-classification and to capture their strategic intent (Hamel and Prahalad, 1990) over time. We classified the subsidiaries in W-T, S-T, S-O and W-O frames as suggested by Figure 4 below. 


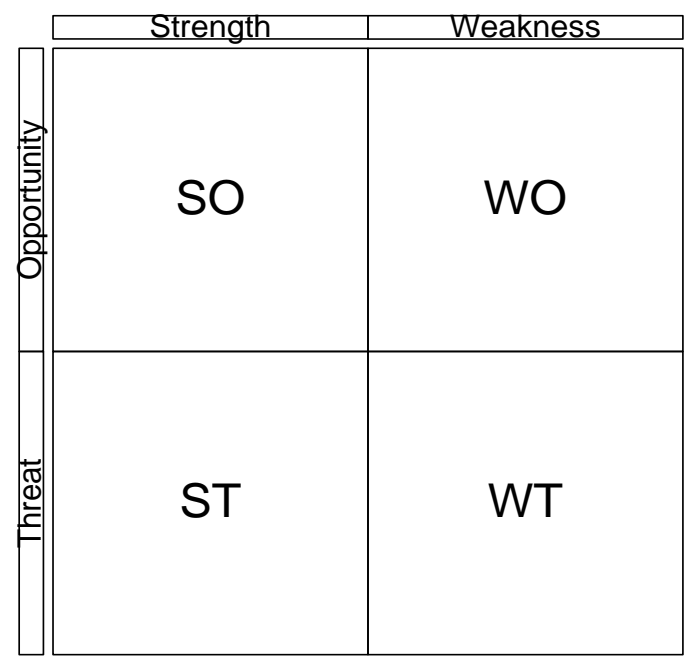

Figure 4

- $\quad$ The WT Strategy (mini-mini). In general, the aim of the WT strategy is to minimize both weaknesses and threats. A company faced with external threats and internal weaknesses may indeed be in a precarious position.

- The WO Strategy (mini--maxi). The second strategy attempts to minimize the weaknesses and to maximize tile opportunities. A company may identify opportunities in the external environment but have organizational weaknesses which prevent the firm from taking advantage of market demands.

- $\quad$ The ST Strategy (maxi-mini). This strategy is based on the strengths of the organization that can deal with threats in the environment. The aim is to maximize the former while minimizing the latter.

- $\quad$ The SO Strategy (maxi-maxi). Any company would like to be in a position where it can maximize both, strengths and opportunities. Such an enterprise can lead from strengths, utilizing resources to take advantage of the market for its products and services. (Weihrich, 1982, pg. 59)

Figure 5 below lists the initial frame proportions of the MNC subsidiaries in our sample. The following exhibits (Tables $3-6$ ) share a common format that permits us to describe the ranked strategic priorities of the subsidiaries we studied in more detail and over time. The rows in the tables list the strategic priorities reported by the firm at various points in time. Those priorities are listed $(a-n)$ in the accompanying notes to each table. Respondents were asked to list their firm's strategic priorities for three points in time. The first was "On Entry". This classification generally refers to the time at which the MNC was founded and began operations in China. In some cases, this point might reflect the entry of a new firm into the country. In others, the point might reflect the conversion of an SOE to a joint venture or to the establishment of an MNC subsidiary in some other form. In all cases, what is captured is the initial strategic intent of the MNC subsidiary as understood by the respondent. The second point in time reflected by our results is "At Present" which generally reflects the set of current strategic priorities. Finally, "In the Future" reports the set of anticipated priorities expected by the respondent at some time in the future. This category is dependent on anticipated performance and the influence of exogenous variables and can be viewed as the least reliable of our reported results. The rows in each table also list the proportion of respondents assigning a given ranking to a strategic priority. Thus, for example, in Table 3 seventy-five point five percent of respondents listed "lowering overall cost" $(b)$ as their top priority on market entry, fifty-eight point four percent list that priority as being foremost at the present time and sixty-seven point six percent expect that priority to be foremost at some future point in time. This finding is consistent with Hamel and Prahalad's assertion that the dominant strategic intent of successful global firms can be expected to be stable over time (1990, pg. 40). A final characteristic of note relating to the exhibits is that blank cells in a table should not be seen as indicating missing data. Instead blank cells in the following exhibits reflect that fewer strategic priorities were reported for that period among our sample than were required in others. In some cases (note the $\mathrm{W}-\mathrm{O}$ frame at-present report in Table 4 below) as few a six strategic priorities were sufficient to capture the strategic intent for the entire sample. The maximum number of strategic priorities required to report our results was fourteen. 
From the collected reports we first report strategies adopted and being adopted by the MNS in the S-O frame, as listed by respondents in Table 3.

Table 3 Evolution of Subsidiaries in the S - O Quadrant

\begin{tabular}{|c|c|c|c|c|c|c|}
\hline \multirow[b]{2}{*}{ Rank } & \multicolumn{2}{|c|}{ On Entry } & \multicolumn{2}{|c|}{ At Present } & \multicolumn{2}{|c|}{ In the Future } \\
\hline & Strategy & $\begin{array}{c}\text { Proportion } \\
(\%)\end{array}$ & Strategy & $\begin{array}{c}\text { Proportion } \\
\text { Percentage } \\
(\%)\end{array}$ & Strategy & $\begin{array}{c}\text { Proportion } \\
\text { Percentage } \\
(\%)\end{array}$ \\
\hline NO. 1 & $b$ & 75.5 & $b$ & 58.4 & $b$ & 67.6 \\
\hline NO. 2 & $k$ & 63.8 & $i$ & 53.9 & $j$ & 65.7 \\
\hline NO. 3 & $\bar{i}$ & 60.6 & $\bar{j}$ & 46.0 & $i$ & 65.5 \\
\hline NO. 4 & $h$ & 56.4 & $h$ & 43.4 & $k$ & 65.5 \\
\hline NO. 5 & $j$ & 46.8 & $k$ & 42.5 & $h$ & 64.9 \\
\hline NO. 6 & $d$ & 42.6 & $g$ & 36.3 & $g$ & 63.1 \\
\hline NO. 7 & $g$ & 39.4 & $d$ & 30.9 & $a$ & 58.1 \\
\hline NO. 8 & $f$ & 38.3 & $f$ & 30.9 & $f$ & 56.9 \\
\hline NO. 9 & $a$ & 31.9 & $l$ & 24.8 & $l$ & 55.7 \\
\hline NO. 10 & $l$ & 26.6 & $a$ & 20.4 & $d$ & 52.7 \\
\hline NO. 11 & $c$ & 12.8 & $m$ & 12.4 & $m$ & 49.2 \\
\hline NO. 12 & $m$ & 8.5 & $c$ & 8.8 & $c$ & 39.4 \\
\hline NO. 13 & $c$ & 5.3 & $e$ & 7.9 & $e$ & 38.4 \\
\hline NO. 14 & $n$ & 1.06 & & & $n$ & 32.1 \\
\hline
\end{tabular}

Notes: $\mathrm{a}-\mathrm{n}$ designate the strategy adopted or intended by the MNC's Subsidiaries in China. In order they are: (a) Expanding the scale of the business, (b) lowering overall cost, (c) M \& A, (d) focus strategy, (e) strategic alliance, (f) differentiation, (g) largest market share, (h) product innovation, (i) marketing innovation, (j) technical innovation, (k) setting up good company's image, (l) developing internally, (m) maintaining the existing situation, (n) retreating in order to advance

Note the dominant priority of overall cost reduction is consistently reported as the top priority of a majority of respondents, past present and future. This is consistent with our prior expectations since dominant competitors often employ such strategies and as we reported above, acquiring a market dominant position often occupies the attention, time and effort of management when resources permit. Next, notice that in the strength - opportunities frame the strategies of focus and differentiation are similarly prioritized. Whether reporting on strategic priorities employed in the past or being employed at present, the subsidiaries of in this frame assign the higher priority to a focus strategy. Thus, we observe that while firms attempt to reduce costs, they also place emphasis on product innovation, marketing innovation, technical innovation, and image than on the adoption of either alternative strategy. In fact, the approach adopted by the firms in our sample is contrary to the strategy of differentiation which relies on the ability to offer products and services that differ significantly from others offered in the market. Because the adoption of a strategy of differentiation causes costs to inevitably increase, multinational corporations in this frame do not attempt to employ this strategy at first. Rather, the firms concentrate on cost reductions to be employed immediately and on product and marketing innovations for later deployment. As markets mature, quality products become the norm for consumers and the nature of demand diverges. Of course, competing based solely on cost advantage becomes less desirable as margins narrow. As it becomes more difficult for the MNS to rely on overall cost leadership and focus strategies alone the firms gradually appeal to consumers through a strategy of differentiation to further establish and consolidate their competitive advantage.

We also note that strength-opportunity frame MNS pay considerable attention to setting up good business reputations, through which they can obtain broad-based awareness of their business practices and support from officials at all levels of the government, as well as promoting a positive business identity to the public. These multinational corporations exhibit awareness of the importance of having established good business image with the government to plans to expand to new markets and to increase market share. Given that the MNS are experiencing more intense competition than they anticipated, the tendencies of strength-opportunity frame subsidiaries to adopt the strategies of technique innovation, market innovation and product innovation early is consistent with good business practices. As far as the strength opportunity type MNS are concerned, the relationship among the above three kinds of innovation is just indicated in Figure 3. 

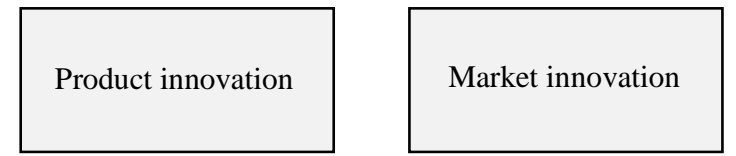

The adoption proportion becomes higher and the

Priority of the initiative becomes stronger over time
Technique innovation

Figure 3 Innovation Strategies Adopted by the Strength-Opportunity Subsidiaries in China

What is interesting too is that the importance of expanding business scale descends from thirty-one point nine percent to twenty point four percent from the market entry to the present. Although strength-opportunity frame subsidiaries in China evaluate the importance of expanding business scale highly, the strategy is now gradually replaced by internal growth strategies. The strength-opportunity frame MNS are inclined to emphasize internal development over other forms. And, although only a handful of subsidiaries have chosen to grow and develop by the method of establishing business alliances or M\&A (merger and acquisition) thus far, a higher proportion report having such activities in mind for the future. In fact, in the past, strategic alliances were not a part of the strategic priorities reported by the firms we studied. Note that setting up new business alliances has become a priority and that the proportion will rise in the future. M\&A initiatives have decreased both in rank and proportion since market entry for the reporting firms (from rank 11 to rank 12 and from $12.8 \%$ to $8.8 \%$ ). We conclude that the strengthopportunity frame MNS in China present a strategic posture of' being the most numerous and active of the firms we sampled, concentrating on the strategy combination that consists of an overall cost leadership as the dominant strategy and strategies for innovation as assisting strategies. We have been able to observe the shifting priorities of the MNS on the S-O frame since market entry and to expose the underlying logic of the innovation strategies reported. Overall, the strategies adopted by the strength-opportunity type MNS in China can be characterized as beginning with overall cost strategies and gradually giving way to focus and differentiation strategies in that order. Next, we turn our attention to the second most populous TOWS frame, the W -T quadrant. From the collected data, we can see the strategies adopted and being adopted the by subsidiaries in W-T quadrant, demonstrated in Table 4.

Table 4 Evolution of Subsidiaries in the W - T Quadrant

\begin{tabular}{|c|c|c|c|c|c|c|}
\hline & \multicolumn{2}{|c|}{ On Entry } & \multicolumn{2}{|c|}{ At Present } & \multicolumn{2}{|r|}{ In the Future } \\
\hline Rank & Strategy & $\begin{array}{c}\text { Proportion } \\
\text { Percentage } \\
(\%)\end{array}$ & Strategy & $\begin{array}{c}\text { Proportion } \\
\text { Percentage } \\
84.6(\%)\end{array}$ & Strategy & $\begin{array}{c}\text { Proportion Percentage } \\
(\%)\end{array}$ \\
\hline NO. 1 & $b$ & 69.2 & $b$ & 84.6 & $b$ & 87.7 \\
\hline NO. 2 & $i$ & 61.5 & $h$ & 46.2 & $i$ & 76.9 \\
\hline NO. 3 & $d$ & 38.5 & $j$ & 46.2 & $h$ & 72.3 \\
\hline NO. 4 & $j$ & 38.5 & $f$ & 30.8 & $j$ & 70.8 \\
\hline NO. 5 & $k$ & 38.5 & $i$ & 30.8 & $g$ & 67.7 \\
\hline NO. 6 & $l$ & 38.5 & $m$ & 30.8 & $k$ & 67.7 \\
\hline NO. 7 & $a$ & 30.8 & $a$ & 23.1 & $a$ & 64.6 \\
\hline NO. 8 & $f$ & 30.8 & $g$ & 23.1 & $d$ & 60 \\
\hline NO. 9 & $h$ & 30.8 & $k$ & 23.1 & $f$ & 58.5 \\
\hline NO. 10 & $m$ & 30.8 & $d$ & 15.4 & $l$ & 55.4 \\
\hline NO. 11 & $g$ & 23.1 & $l$ & 15.4 & $m$ & 55.4 \\
\hline NO. 12 & $e$ & 15.4 & $c$ & 7.69 & $e$ & 38.5 \\
\hline NO. 13 & $c$ & 7.69 & $e$ & 7.69 & $c$ & 33.8 \\
\hline NO. 14 & $n$ & 7.69 & & & $n$ & 30.8 \\
\hline
\end{tabular}

Notes: $\mathrm{a}-\mathrm{n}$ designate the strategy adopted or intended by the MNC's Subsidiaries in China. In order they are: (a) Expanding the scale of the business, (b) lowering overall cost, (c) M \& A, (d) focus strategy, (e) strategic alliance, (f) differentiation, (g) largest market share, (h) product innovation, (i) marketing innovation, (j) technical innovation, (k) setting up good company's image, (l) developing internally, (m) maintaining the existing situation, (n) retreating in order to advance. 
The weakness-threat frame subsidiaries in China occupy second highest (twelve percent) frame we have examined. We note with interest that these firms report market entry strategies that included both focus and differentiation in addition to overall cost leadership. Perhaps the apparent lack of unambiguous focus has resulted in the weak competitive position reported by our respondents. A competitive position self-reported as relatively weak combined with a high level of perceived competitive pressure has caused the weakness-threat frame MNS in China to abandon the strategy of focus and differentiation in favor resort to the strategy of overall cost leadership (we note that the strategies decline from rank 3 to 8 and from rank 8 to rank 9 respectively). The next highest priorities of the weakness-threat frame MNS in China emphasize market innovation, product innovation and technique innovation despite of their competitively disadvantageous position. We also note with interest and surprise that the weaknessthreat frame subsidiaries in China give greater weight (higher rankings) to product innovation strategies than do weakness-opportunity frame MNS in China when the reverse would seem to be more likely the case. Our measures of product innovation were divided into imitative innovations and first-time innovations. The weakness-threat type subsidiaries in China lay more emphasis on the former method than the latter to exploit the market. A significant proportion of the reporting MNS in China (30.8\%) realize that such innovation is required merely to maintain the current competition position. In addition, at market entry the weakness-threat type subsidiaries in China (fifteen point four percent $15.4 \%$ ) chose to establish business alliance to obtain resources, but now only half that proportion still report aspiring to this strategy. Worthy of note too, is that the weakness-threat frame MNS are to a very high degree dependent on themselves alone for resources that might be available by establishing business alliances or through M\&A. Their attitude toward the acquiring strategic resources is both clear and consistent.

Taken as a group then, the weakness-threat frame subsidiaries present a strategic posture we characterize as one of active maintenance, consisting of strategies in which innovation is predominant, with strategies of corporate identity and diversification as assisting strategies. From this description of the $\mathrm{W}-\mathrm{T}$ frame we turn our attention next to the $\mathrm{S}-\mathrm{T}$ frame.

Those strategies adopted and being adopted the by subsidiaries in S-T quadrant, are demonstrated in Table 5. The first distinguishable finding of interest is that the subsidiaries in the S-T frame collectively choose very stable strategy combinations. Whether we consider the past (market entry) strategy or the present strategy being employed, these subsidiaries always regard the strategy of overall-cost leadership to be their first choice and the differentiation strategy as their last. We observed that this set of firms actively sought to use their strengths in production to accommodate diversification while increasing capacity utilization and increasing market share.

Table 5 Evolution of Subsidiaries in the $\mathrm{S}$ - T Quadrant

\begin{tabular}{|c|c|c|c|c|c|c|}
\hline \multirow[b]{2}{*}{ Rank } & \multicolumn{2}{|c|}{ On Entry } & \multicolumn{2}{|c|}{ At Present } & \multicolumn{2}{|c|}{ In the Future } \\
\hline & Strategy & $\begin{array}{c}\text { Proportion } \\
\text { Percentage } \\
(\%) \\
\end{array}$ & Strategy & $\begin{array}{c}\text { Proportion } \\
\text { Percentage } \\
\text { 84.6(\%) } \\
\end{array}$ & Strategy & $\begin{array}{c}\text { Proportion } \\
\text { Percentage } \\
(\%) \\
\end{array}$ \\
\hline NO. 1 & $b$ & 100 & $b$ & 100 & $b$ & 87.7 \\
\hline NO. 2 & $g$ & 75 & $g$ & 75 & $i$ & 76.9 \\
\hline NO. 3 & $a$ & 50 & $i$ & 75 & $k$ & 72.3 \\
\hline NO. 4 & $d$ & 50 & $a$ & 50 & $g$ & 70.8 \\
\hline NO. 5 & $f$ & 50 & $h$ & 50 & $j$ & 67.7 \\
\hline NO. 6 & $i$ & 50 & $k$ & 50 & $h$ & 67.7 \\
\hline NO. 7 & $j$ & 50 & $m$ & 50 & $a$ & 64.6 \\
\hline NO. 8 & $k$ & 50 & $d$ & 25 & $m$ & 60 \\
\hline NO. 9 & $m$ & 50 & $e$ & 25 & $d$ & 58.5 \\
\hline NO. 10 & $c$ & 25 & $f$ & 25 & $f$ & 55.4 \\
\hline NO. 11 & $h$ & 25 & $j$ & 25 & $l$ & 55.4 \\
\hline NO. 12 & & & & & $c$ & 40 \\
\hline NO. 13 & & & & & $e$ & 40 \\
\hline NO. 14 & & & & & $n$ & 35 \\
\hline
\end{tabular}

Notes: $\mathrm{a}-\mathrm{n}$ designate the strategy adopted or intended by the MNC's Subsidiaries in China. In order they are: (a) Expanding the scale of the business, (b) lowering overall cost, (c) M \& A, (d) focus strategy, (e) strategic alliance, (f) differentiation, (g) largest market share, (h) product innovation, (i) marketing innovation, (j) technical innovation, (k) setting up good company's image, (l) developing internally, (m) maintaining the existing situation, (n) retreating in order to advance. 
The priority assigned to gaining market share was unique to the $\mathrm{S}-\mathrm{T}$ frame group. Compared with other subsidiaries with weak opportunities, these subsidiaries prefer to actively explore the market and to build share through diversification strategies. Furthermore, most subsidiaries chose concentric diversification, namely growing and developing in the same or in a related industry. By this means, subsidiaries in the S-T quadrant not only enhance their core competitive advantage (efficient production), but also spread and diffuse operational risks and exploit the market effectively. Despite of the threats they perceive from the external environment, these subsidiaries steadfastly regard the maximization of their market share as the predominant goal. Consequently, they gradually adjust the core of their strategies to the strategy of innovation represented by market innovation based on keeping pace with active programs of diversification. From the perspective of the recognition of the importance of the strategies, the subsidiaries in the S-T quadrant pay more and more attention than others to the strategies of M\&A and establishing strategic alliances. Therefore, these subsidiaries try to realize their growth and developing strategies through diversification to obtain the required strategic resources (access to distribution networks, host country brands, and raw materials).

Generally speaking, it can be said that the subsidiaries in the S-T frame have adopted strategies dominated by diversification to a greater extent than those in the $\mathrm{S}-\mathrm{T}$ and $\mathrm{W}-\mathrm{T}$ frames. At the same time the importance of the strategies of innovation and corporate identity has been increasing incrementally. As alliances and brands mature this can be expected to continue. We next turn our attention to our least populous TOWS frame, the W - O quadrant.

Table 6 reports the strategies adopted and being adopted by subsidiaries in W-O quadrant. At the point of market entry the first order of priority for this group of firms is no different from the others we have discussed. However, we see that market innovation has displaced overall-cost leadership at present, albeit temporarily. What can be seen, however, is that the weakness-opportunity frame subsidiaries in China seem to uniformly prefer the focus strategy to that of differentiation. The fundamental reason we infer is that their disadvantageous competitive situation makes them resist the pressure to effectively incur the increased costs associated with a strategy of differentiation enacted on a broad scale. Secondly, the occupants of the weakness-opportunity frame in China attach greater importance to the strategies of innovation and corporate identity from the beginning than do others. In addition, they completely depend exclusively on their internal development without adopting the strategy of M\&A and or establishing business alliances.

Table 6 Evolution of Subsidiaries in the W - O Quadrant

\begin{tabular}{|c|c|c|c|c|c|c|}
\hline \multirow[b]{2}{*}{ Rank } & \multicolumn{2}{|c|}{ On Entry } & \multicolumn{2}{|c|}{ At Present } & \multicolumn{2}{|c|}{ In the Future } \\
\hline & Strategy & $\begin{array}{c}\text { Proportion } \\
\text { Percentage } \\
(\%)\end{array}$ & Strategy & $\begin{array}{c}\text { Proportion } \\
\text { Percentage } \\
(\%) \\
\end{array}$ & Strategy & $\begin{array}{c}\text { Proportion } \\
\text { Percentage } \\
(\%) \\
\end{array}$ \\
\hline NO. 1 & $b$ & 100 & $i$ & 100 & $b$ & 100 \\
\hline NO. 2 & $d$ & 100 & $b$ & 100 & $j$ & 100 \\
\hline NO. 3 & $j$ & 100 & $d$ & 50 & $i$ & 90 \\
\hline NO. 4 & $g$ & 50 & $f$ & 50 & $a$ & 80 \\
\hline NO. 5 & $h$ & 50 & $h$ & 50 & $d$ & 80 \\
\hline NO. 6 & $i$ & 50 & $k$ & 50 & $g$ & 80 \\
\hline NO. 7 & $k$ & 50 & & & $f$ & 70 \\
\hline NO. 8 & $m$ & 50 & & & $h$ & 70 \\
\hline NO. 9 & $n$ & 50 & & & $k$ & 70 \\
\hline NO. 10 & & & & & $e$ & 60 \\
\hline NO. 11 & & & & & $l$ & 50 \\
\hline NO. 12 & & & & & $m$ & 50 \\
\hline
\end{tabular}

Notes: a $-\mathrm{n}$ designate the strategy adopted or intended by the MNC's Subsidiaries in China. In order they are: (a) Expanding the scale of the business, (b) lowering overall cost, (c) M \& A, (d) focus strategy, (e) strategic alliance, (f) differentiation, (g) largest market share, (h) product innovation, (i) marketing innovation, (j) technical innovation, (k) setting up good company's image, (l) developing internally, (m) maintaining the existing situation, (n) retreating in order to advance. 
Unlike the strength-opportunity frame subsidiaries in China, the weakness-opportunity type subsidiaries in China present a strategic posture that reflects a greater degree of variability. We note the priority assigned to "setting up good company's image" is lower than that assigned to it by those in the $\mathrm{S}-\mathrm{O}$ frame. Concretely, this indicates either a lack of awareness of a strategic factor seen by other groups as critical or an absence of the opportunities and resources required to pursue the priority. The evidence suggests the former is more likely the case, based on the prospective ranking of the factor (rank 9). While attempting to maintain their current competition position, the weakness-opportunity frame subsidiaries in China adopt strategies combining a focus on corporate identity and innovation, and seek new growth opportunities and resources from their parents. Thus, the weaknessopportunity frame subsidiaries in China present a strategic posture that can be described as less stable than others and focusing more internally than externally.

\section{SUMMARY, CONCLUSIONS, LIMITATIONS AND DIRECTIONS FOR FUTURE RESEARCH}

This has been a study of the evolution of strategies among large multinational firms doing business in China. We report the motivations, actions and aspirations of the managers of largest multinational subsidiaries operating in China. The first part of our research related to the ownership and industry characteristics respondents, nearly one-third were at the CEO or board level. Twenty-two industries were represented. We found that the dominant strategy employed by multinational corporations in establishing MNC subsidiaries (MNS) in China is overall cost leadership. Our research suggests that the role of the MNS does not always remain fixed over time. Adjustments to MNS role in our sample, though infrequent, have shifted roles from production-based to more market based roles. We have also found that the primary investment motivation of MNS in China has changed from "low labor cost" to "exploiting Chinese market". We tracked and described the ways in which "market explorer" MNS behave from market entry through the growth and expansion phases of development. We observed that during the expansion phase in particular MNS emphasis shifted to overall competitive advantage through product, market and technology innovations developed to reinforce its market presence. We observe that once MNS managers gain awareness and mastery in dealing with the local and global adversities in the complex host country conditions, they become more broadly able to accomplish the strategic mission of the MNS. Nearly ninety percent of firms we sampled considered the competitive environment they faced to be intense. Using the TOWS approach (Weirich, 1982) we classified the strategic posture of MNS subsidiaries in China into four discrete frames (or quadrants). We found that MNS in China, in spite of occupying different strategic or frames (S-O, S-T, W-O and W-T), all chose either a developing or a maintaining strategy. The TOWS frame of analysis provides a base that is helpful to analyze and comprehend the strategic similarities and difference among MNS. The results from our study applying the TOWS approach have allowed us to expose the trend of strategic evolution.

The research results show that there is significant variation in the strategic posture exhibited by MNS. This difference is shown in each of the four frames. In the S-O quadrant MNS in China adopt a consistent developing strategy based on overall cost leadership. Overall, the strategies adopted by the strength-opportunity frame MNS in China can be characterized as beginning with overall cost strategies and gradually giving way to focus and differentiation strategies in that order. In the W- O frame MNS in China seek active development on the basis of maintenance, concentrating on product-innovation centered innovating strategy. Further, weakness-opportunity frame MNS seem to uniformly prefer the focus strategy to that of differentiation. Furthermore, the occupants of the weakness-opportunity frame in China attach greater importance to the strategies of innovation and corporate identity from the beginning than do others. In addition, they depend exclusively on internal development without adopting the strategy of M\&A and or establishing business alliances. Taken as a group the weakness-threat $\mathrm{W}-\mathrm{T}$ frame MNS present a strategic posture we characterize as one of active maintenance, consisting of strategies in which innovation is predominant, with strategies of corporate identity and diversification as assisting strategies. Generally speaking, it can be said that the subsidiaries in the S-T frame have adopted strategies dominated by diversification to a greater extent than those in the $\mathrm{S}-\mathrm{T}$ and $\mathrm{W}-\mathrm{T}$ frames. At the same time the importance of the strategies of innovation and corporate identity increase incrementally. As alliances and brands mature this can be expected to continue.

Our results are limited due to the imperfections and limitations in our sample. The fact that only thirty percent of respondents were strategic managers calls into question whether the homogeneity of the sample can be relied upon to accurately reflect the actual strategic intent of the firms whose strategies and aspirations we sought to 
capture and report. Resource limitations prevented us from expanding the sample to a larger group. We are consoled by the fact that the largest firms were represented and that top managers' observations were included. We have limited our findings to descriptions that we believe will aid the reader in better understanding the evolution of strategies in a descriptive sense. A second limitation that should be acknowledged relates to language. We surveyed managers using instruments in Mandarin and English. This limitation was imposed by the nationalities of the authors and by our desire to maintain control over the survey. We have noted above that more than half our sample respondents were from either South Korea or from the European Union. Thus, despite our best efforts we know that some information has certainly been lost in translation. The small numbers available to us for examination in the less well-populated frames of the TOWS analysis beg the question of generalizability beyond our sample. Surely, we would have preferred it otherwise. Future researchers taking up this topic would be well advised to improve on the methodology we have employed.

\section{AUTHOR INFORMATION}

Ronald J. Salazar, Ph.D., University of Houston-Victoria, 14000 University Boulevard, Sugar Land, TX 77479, USA. E-mail: salazarr@uhv.edu (Corresponding author)

Jifu Wang, Ph.D., University of Houston-Victoria, 14000 University Boulevard, Sugar Land, TX 77479, USA. E-mail: wangj@uhv.edu

\section{REFERENCES}

1. Agarwal, R., \& Helfat, C. E. 2009. Strategic Renewal of Organizations. Organization Science, 20 (2): 281293.

2. Amit, R., \& Shoemaker, P., 1993, Strategic assets and organizational rent. Strategic Management Journal, 14, (1): 33-46.

3. Arpan, J.S. \& Ricks, D.A.1986. Foreign direct investment in the US, 1974-1984. Journal of International Business Studies, 17(3): 149-153.

4. Barney, J. 1991. Firm resources and sustained competitive advantage. Journal of Management, 17: 99120.

5. Bartlett, C.A. \& Ghoshal, S. 1989. Managing across borders: The transnational solution. Boston: Harvard Business School Press.

6. $\quad$ Brewer, T.L. 1993. Transnational Management, $2^{\text {nd }}$. Ed. Chicago, IL: Irwin.

7. Birkinshaw, J., \& Hood, N. 1998. Multinational subsidiary evolution: Capability and charter change in foreign-owned subsidiary companies. Academy of Management Review, 23:4, 773-795.

8. Božac, M., \& Tipurić, D. (2008). Developing Strategic Initiatives with the TOWS Matrix- - Croatia Insurance Company SWOT Analysis. Conference Proceedings: International Conference of the Faculty of Economics Sarajevo, (ICES), 98-100.

9. Buckley, P.J., \& Casson, M. 1976. The future of the multinational enterprise. London: Macmillan.

10. Caves, R.E. 1971. International corporations: The industrial economics of foreign investment. Economica, 38(149): 1-27.

11. Cheng, LK., \& Kwan, YK. 2000. What are the determinants of the location of foreign direct investment? The Chinese experience. Journal of International Economics, 51(2): 379-400.

12. Chun-Chu, L. 2007. A Model for Innovation Strategies CDFAs in Taiwan. International Research Journal of Finance \& Economics, (8), 31-40.

13. Cohen, B.I., \& Rugman. A.M. 1976. Risk reduction by international diversification. Journal of International Business Studies, Fall/Spring: 75-80.

14. Das, T.K., \& Teng, B. 2000. A resource-based theory of strategic alliances. Journal of Management, 26(1): 31-61.

15. Dunning, J.H. 1993. Multinational enterprises and the global economy. Wokingham, England: AddisionWesley.

16. Froot, K. A., \& Stein, J.C. 1991. Exchange rates and foreign direct investment: An imperfect capital markets approach. Quarterly Journal of Economics, 106(4): 1191-1217. 
17. Furman, J., Porter, M., \& Stern, S. 2002. The determinants of national innovative capacity. Research Policy, 39(6): 899-936.

18. Ghazinoory, S., Zadeh, A., \& Memariani, A. 2007. Fuzzy SWOT analysis. Journal of Intelligent \& Fuzzy Systems, 18(1), 99-108.

19. Grant, R.M. 1991. The resource-based theory of competitive advantage: Implications for strategy formulation. California Management Review, 33 (Spring): 114-135.

20. Grubert, H., \& Mutti, J. 1991. Taxes, tariffs and transfer pricing in multinational corporate decision making. Review of Economics and Statistics, 73(2): 285-293.

21. Hartman, D.G. 1984. Tax policy and foreign direct investment in the United States. National Tax Journal, 37: 475-487.

22. Hamel, G., \& Prahalad, C. K.1990. Strategic Intent. McKinsey Quarterly, (2), 36-61.

23. Henley, J, Kirkpatrick, C, \& Wilde, G. 1999. Foreign direct investment in China: Recent trend and current policy issues, World Economy, 22(2): 23-43.

24. Horne, S., \& Kerr, K. 2003. Equipping Youth for the 21st Century: The Application of TOWS Analysis to a School Subject. Journal of Nonprofit \& Public Sector Marketing, 11(2): 1-19.

25. Huber, G. P. 1991. Organizational Learning: The Contributing Processes and the Literatures, Organization Science, 2 (1): 88-115.

26. Kalyanaram, G., Robinson, W., \& Urban, G. 1995. Order of Market Entry: Established Empirical Generalizations, Emerging Empirical Generalizations and Future Research. Marketing Science. 14(3), G212.

27. Kersan-Škabić, I., \& Tijanić, L. 2009. The Challenges of Competitiveness in Southeast European Countries. South East European Journal of Economics \& Business.

28. Kogut, B., \& Chang, S.J. 1996. Platform investments and volatile exchange rates: Direct investment in the US by Japanese electronic companies. Review of Economics and Statistics, 78(2): 221-231.

29. Lee, Guang-Yao, Liu, Y., Wu, K., \& Shi, Y., 1996. Supporting economic reform of the Chinese Petroleum industry: A dynamic decision making model. The Engineering Economist, 42 (1): 1-18.

30. Lu, J.W. and Beamish, P.W. 2001. The internationalization and performance of SMEs. Strategic Management Journal, 22(7): 565-583.

31. Makinoa, S., Beamish, P., \& Zhao, N. 2004. The characteristics and performance of Japanese FDI in less developed and developed countries. Journal of World Business, 39(4), 377-392.

32. Miles, Raymond E.; Miles, Grant; Snow, Charles C.; Blomqvist, Kirsimarja; Rocha, Hector. 2009., The IForm Organization. California Management Review, 51 (4): 61-76.

33. Miles, Raymond E. and Snow, Charles C. 1978. Organizational strategy, structure, and process. New York: McGraw-Hill Book Co.

34. Miller, K.D. 1993. Industry and country effects on managers' perceptions of environmental uncertainties. Journal of International Business Studies, 24 (4): 693-714.

35. Oswald, S. L., Mossholder, K. W. \& Harris, S. G., 1997., Relations Between Strategic Involvement and Managers' Perceptions of Environment and Competitive Strengths. Group \& Organization Management. 22 (3): 343-365.

36. Orr, D. 1973. Foreign control and foreign penetration in the Canadian manufacturing industries. Unpublished manuscript. University of British Columbia, Vancouver.

37. Porter, M.E. 2000a.New global strategies for competitive advantage. Planning Review, 18(3):4-15.

38. Porter, M.E. 2000b. The competitive advantage of nations. Harvard Business Review. 68(2), p. 73-94.

39. Root, F. 1990. International investment and trade. Cincinnati, OH: Southwestern.

40. Southwest Economy 2005 (4). Publication of Federal Reserve Bank of Dallas.

41. Stavrevski, Z., Deputy Prime Minister of Macedonia. 2007. Lecture at CIFIT, March.

42. Steensma, K, Tihanyi, L., Lyles, M.A. \& Dhanraj, C., 2005. The evolving value of foreign partnerships in transitional economies. Academy of Management Journal, 48(2), 213-235.

43. Svetlicic, M. \& Rojec, M. 1994. Foreign direct investment and the transformation of Central European economies. Management International Review, 34: 293-312.

44. Tang, M., \& Yu, C.J. 1990. Foreign market entry: production-related strategies. Management Science, 36 (4): 476-489.

45. Wei, S.J. 2000. How taxing is corruption on international investors. Review of Economics and Statistics. 82(1): 1-11. 
46. Weihrich, H. 1982. The TOWS Matrix - A Tool for Situational Analysis, Long Range Planning. 15 (12): 54-66.

47. Wernerfelt, B.1984. A Resource-based View of the Firm. Strategic Management Journal. 5 (2): 171-80.

48. Xing, Y, 2006. Why is China so attractive for FDI? The role of exchange rates. China Economic Review, 17(2): 198-209.

49. Zhang, KH. 2001. What attracts foreign multinational corporations to China? Contemporary Economic Policy. 19(3): 336-346.

50. Zitta, S.J., \& Powers, T.L. 2003. Motives for Foreign Direct Investment in the U.S. The Thunderbird International Business Review, 45(3), 276-388. 